Rev. Int. Contam. Ambie. 33 (4) 575-590, 2017

DOI: 10.20937/RICA.2017.33.04.03

\title{
CHARACTERIZATION OF DISSOLVED ORGANIC MATTER IN AN AGRICULTURAL WASTEWATER-IRRIGATED SOIL, IN SEMI ARID MEXICO
}

\author{
Rosa María FUENTES RIVAS ${ }^{1,2 *}$, Germán SANTACRUZ DE LEÓN ${ }^{3}$, José Alfredo RAMOS LEAL 2 , \\ Janete MORÁN RAMÍREZ ${ }^{2}$ and Francisco MARTÍN ROMERO ${ }^{4}$
}

${ }^{1}$ Facultad de Geografía, Universidad Autónoma del Estado de México. Cerro de Coatepec, Ciudad Universitaria, Toluca estado de México, México, C. P. 50110

${ }^{2}$ División de Geociencias Aplicadas, Instituto Potosino de Investigación Científica y Tecnológica. Camino a la Presa San José 2055, Colonia Lomas, 4a. Sección, San Luis Potosí, San Luis Potosí, México, C. P. 78216

${ }^{3}$ El Colegio de San Luis, C.A. Parque de Macul, 155, Fraccionamiento Colinas del Parque, San Luis Potosí, San Luis Potosí, México, C. P. 78294

${ }^{4}$ Instituto de Geología, Universidad Nacional Autónoma de Mexico. Avenida Universidad 3000, Ciudad Universitaria, Coyoacán, Ciudad de México, México, C. P. 04510

*Corresponding author: rmfuentesr@uaemex.mx

(Received March 2016; accepted April 2017)

Key words: 3D fluorescence, aromatic proteins, humic acids, fulvic acids, anthropogenic pollution

\begin{abstract}
Most agricultural soils in semi-arid regions present a deficiency of organic matter (SOM). In order to improve this soil, wastewater is used due to its high organic carbon content. The objective of the present work was to characterize the dissolved organic matter in five residual water samples and ten soil samples from the agricultural area of the municipality of San Luis Potosí by 3D fluorescence spectroscopy. The changes in some physical and chemical properties of the soil were also analyzed. The soil samples were collected at different depths to observe the anthropogenic organic matter presence, their retention in the soil profile, their fluorescence intensity changes and their migration into the aquifer. Temperature, electrical conductivity, dissolved oxygen, oxidation- reduction potential and total dissolved solids were determined in situ. The major anions and cations: $\mathrm{Na}^{+}, \mathrm{K}^{+}, \mathrm{Mg}^{2+}, \mathrm{Ca}^{2+}, \mathrm{PO}_{4}{ }^{3-}, \mathrm{SO}_{4}{ }^{2-}, \mathrm{NO}^{3-}, \mathrm{NO}_{2}{ }^{-}$, were analysed in laboratory. The results show the great contribution of organic matter $(>2020 \mathrm{mg} / \mathrm{L})$ in the residual water used for irrigation, as well as, the low content of SOM. The physical and chemical results indicate that the high electrical conductivity of the water, represents a risk of salinization for soils, but not of short term sodicity. The 3D fluorescence spectra of the soil profile, shows the presence of humic and fulvic acids, aromatic proteins and products of microbial degradation. The latter observed in that depth where there is a greater percentage of clay.
\end{abstract}

Palabras clave: fluorescencia 3D, proteínas aromáticas, ácidos húmicos, ácidos fúlvicos, contaminación de suelo

\section{RESUMEN}

La mayoría de los suelos agrícolas en regiones semiáridas presentan una deficiencia de materia orgánica (MOS) y para compensarla se recurre al uso de agua residual por 
su alto contenido de carbono orgánico. El objetivo del presente trabajo fue caracterizar la materia orgánica disuelta con espectroscopía de fluorescencia 3D, en cinco muestras de agua residual y 10 de suelo de la zona agrícola del municipio de San Luis Potosí. Se analizaron los cambios de algunas propiedades físicas y químicas del suelo y del agua. Las muestras se colectaron a diferentes profundidades para observar la presencia de materia orgánica, su retención a lo largo del perfil de suelo y su migración hacia el acuífero. La temperatura, la conductividad eléctrica, el oxígeno disuelto, el potencial de oxido-reducción y los sólidos totales disueltos se determinaron in situ. En laboratorio fueron analizados los aniones y cationes mayoritarios: $\mathrm{Na}^{+}, \mathrm{K}^{+}, \mathrm{Mg}^{2+}, \mathrm{Ca}^{2+}, \mathrm{PO}_{4}{ }^{3-}$, $\mathrm{SO}_{4}{ }^{2-}, \mathrm{NO}^{3-}, \mathrm{NO}_{2}{ }^{-}$. Los resultados muestran el gran aporte de materia orgánica del agua residual empleada para el riego, así como, el bajo contenido de MOS. Los resultados físicos y químicos indican que la alta conductividad eléctrica del agua representa un riesgo de salinización para los suelos, pero no de sodicidad a corto plazo. Los espectros de fluorescencia 3D del perfil del suelo evidencian la presencia de ácidos húmicos, acidos fúlvicos, proteínas aromáticas y productos de degradación microbiana. Estos últimos, observados en la profundidad donde se presenta mayor contenido de arcilla.

\section{INTRODUCTION}

Soil organic matter (SOM) comprises all substances of biological origin, i.e. plant and animal residues (Lehmann et al. 2007, Hernández-Soriano et al. 2013). $\mathrm{SOM}$ is essential in soil biogeochemical processes (Bot and Benites 2005), and improves soil structure and soil minerals. It lightens clay soils, reduces soil erodibility and improves water retention and infiltration, especially in sandy soils (Edwards et al. 2000, Sustaita et al. 2000, Caravaca et al. 2001, Navarro and Navarro 2003, Morgan 2005, Ibarra-Castillo et al. 2007, Mavi 2012, Corral-Nuñez et al. 2014).

The main SOM sources are: 1) allochthonous or external, such as surface runoff from uphill soils, or runoff seeping through leaves, twigs, trunks and litter (Zech and Guggenberger 1996), 2) autochthonous or generated sources in the soil by natural organic matter (NOM) decomposition, that it is later on released by microbial metabolites and root exudates, wich includes humic and fulvic acids (McDowell and Likens 1988, Guggenberger et al. 1994, Guggenberger and Kaiser 2003), and 3) anthropogenic, made of synthetic organic substances, usually of industrial origin (Mostofa and Sakugawa 2009), often found in wastewater.

SOM is found in two phases: solid as particulate organic matter, and liquid as dissolved organic matter (DOM), an important constituent of soil solution that plays a role in many chemical and biological processes in soils. DOM can be defined as organic matter that passes through a $0.45 \mu \mathrm{m}$ mesh sieve (Kalbitz et al. 2000, Zsolnay 2003). DOM is less than $0.25 \%$ of all SOM (Ohno et al. 2007) but plays crucial ecological roles linking the geosphere and hydrosphere, the biosphere and abiotic realms
(Akagi et al. 2007). DOM is considered the most labile and reactive of SOM's multicomponents (Ohno et al. 2007), which is mobile, soluble, and usually contains labile organic molecules that are nutrients and energy sources for microorganisms (Brooks et al. 1999). DOM can determine soil formation and structure (Stevenson 1994, Lundström et al. 1995), and intervenes in transport of nutrients and pollutants (Kalbitz and Popp 1999, Zsolnay 2003).

DOM in soil can be natural or of anthropogenic origin. Natural dissolved organic matter (NDOM) is constituted by low molecular weight substances such as organic acids and amino acids, as well as complex high molecular weight molecules: humic and fulvic acids, and enzymes (Yuan et al. 2013). Organic matter from anthropogenic origin (ADOM) is incorporated into the soil by wastewater irrigation or water from industrial effluents, which includes a variety of chemical compounds: carbohydrates, aromatic proteins, amino acids, carboxylic acids, aldehydes, alcohols, and phenols, among others (Domenech and Peral 2006).

Determining the SOM is essential to establish the fertility and productivity of agricultural and forest soils (Davel and Ortega 2003, Álvarez and Steinbach 2006). Globally, there are naturally fertile soils, but in many places, soils are infertile or lose nutrients. To compensate for low SOM contents, direct layout of compost or irrigation with wastewater is carried out on agricultural plots. Worldwide, agricultural use is $70 \%$ of all water uses (FAO 2013). Lack of natural water sources has driven the recent increase of agricultural irrigation that uses domestic or municipal wastewaters (Chen et al. 2010, Morugan-Coronado et al. 2011, FAO 2013). Overall, 20 million ha or $10 \%$ of all irrigated lands, are 
irrigated with treated or untreated wastewaters (Brzezinska et al. 2011, FAO 2013). In Mexico, irrigated lands are 6.1 million ha (Nikolskii-Gavrilov et al. 2014), of which 250000 are irrigated with wastewater (Jiménez 2005). Arid and semiarid lands represent $60 \%$ of all land in Mexico and $73.5 \%$ in the state of San Luis Potosi, where wastewater irrigation is a common practice today (CONAGUA 2014).

For farmers without access to natural water sources, the benefit of irrigation with wastewater containing DOM and nutrient contents, help them reduce the need for chemical fertilizers (FAO 2013). In natural water, organic matter content measured as chemical oxygen demand (COD), is $9-16 \mathrm{mg} / \mathrm{L}$ (Metcalf and Eddy 2003), compared to $260-900 \mathrm{mg} / \mathrm{L}$ COD in wastewaters with entrained domestic and industrial waste (Feigin et al. 1991, Metcalf and Eddy 2003, Chen et al. 2010). Therefore, wastewater has become essential in arid land agriculture (Feigin et al. 1991, Rusan et al. 2007, Chen et al. 2010, Gotosa et al. 2011), in contrast to the non-arid land, where their SOM content is higher.

The SOM content can be positively or negatively affected by wastewater irrigation, because it can improve soil fertility or cause its contamination by heavy metals accumulation at the same time (Jüeschke 2009, Bernier et al. 2013). Several studies have focused on identifying the effects of wastewater irrigation on physical and chemical properties of soil. However, the results showed no evidence to suggest that irrigation with wastewater affect the relative abundance of hydrophobic aliphatic groups in SOM. Other authors reported that soil quality conditions were affected, such as total soil carbon and nitrogen, mineral nitrogen in soil solution, microbial activity, composition of microbial communities and their function, exchangeable calcium and magnesium, salinity, sodicity, clay dispersion and hydraulic conductivity (Abedi-Koupai et al. 2006, Bhardwaj et al. 2007, Fonseca et al. 2007, Rusan et al. 2007, Walker and Lin 2008, Gotosa et al. 2011).

Other investigations on this topic have been carried out, specifically, the effects on soil composition, texture, changes on SOM quantity and effects on physical and chemical properties, as cation exchange capacity. Bernier in 2013 reported that loamy-sand soil was enriched by hydrophilic groups under both short and long-term irrigation. But no relation was established between the accumulation of hydrophobic components in SOM and clay or sand content in soils. (Jüeschke 2009, Chen et al. 2010, Bernier et al. 2013). The DOM in wastewater is added or removed of soil profile by a combination of physical, biological and chemical processes, mostly to superficial soil horizons (Quanrud et al. 1996, Westerhoff and Pinney 2000, Quanrud et al. 2003, Xue et al. 2009). DOM levels along the soil profile, its contribution from wastewater DOM additions, and their relation to soil physical and chemical parameters are little known despite their relevance to arid land agriculture.

The aim of this study was to characterize the dissolved organic matter (DOM) by 3D fluorescence spectroscopy, in five samples of residual water and 10 samples of soil, in order to observe the effects of irrigation with wastewater, as well as changes in the physical and chemical properties of both, soil and water.

\section{MATERIALS AND METHODS}

\section{Study site}

The study area is located in a narrow plain (1850 y 1900 masl) nearby the city of San Luis Potosí, in a semiarid region of Mexico (Fig. 1). The predominant soils in the study area are: haplic xerosols combined with rendzinas, haplic phaeozems and leptosols. All of them have characteristics, which combined with climatic conditions (low rainfall, high evaporation, low humidity, etc.), limit agricultural productivity. To compensate for the low SOM contents, the use of compost or wastewater is usually carried out on agricultural plots. Wastewater irrigation in this area is common since 1920 (Cirelli 2004) and it is considered an important nutrient source, which can augment soil productivity (Salazar-Ledesma 2011). Irrigation wastewater is pumped from the Españita river, now a collector for domestic and industrial wastewater from the city of San Luis Potosí.

\section{Irrigation water sampling and characterization}

Five composed water samples were taken from the Españita river (Fig. 1). Field parameters were measured for each sample: temperature (T), $\mathrm{pH}$, dissolved oxygen (DO), total dissolved solids (TDS), electric conductivity (EC) and oxidation-reduction potential (ORP). In the laboratory of the Comision Nacional del Agua (National Water Commission), major anions and cations were also determined: chlorine $\left(\mathrm{Cl}^{-}\right)$, sulfate $\left(\mathrm{SO}_{4}{ }^{2-}\right)$, nitrate $\left(\mathrm{NO}_{3}{ }^{-}\right)$, nitrite $\left(\mathrm{NO}_{2}^{-}\right)$and ammonium $\left(\mathrm{NH}_{4}^{+}\right)$as well as chemical oxygen demand (COD).

\section{Agricultural soil sampling characterization}

Eight points were selected at random in a 200 ha irrigated area of ejido (communal property) Rancho Viejo. At each point, one $0-30 \mathrm{~cm}$ deep and one 


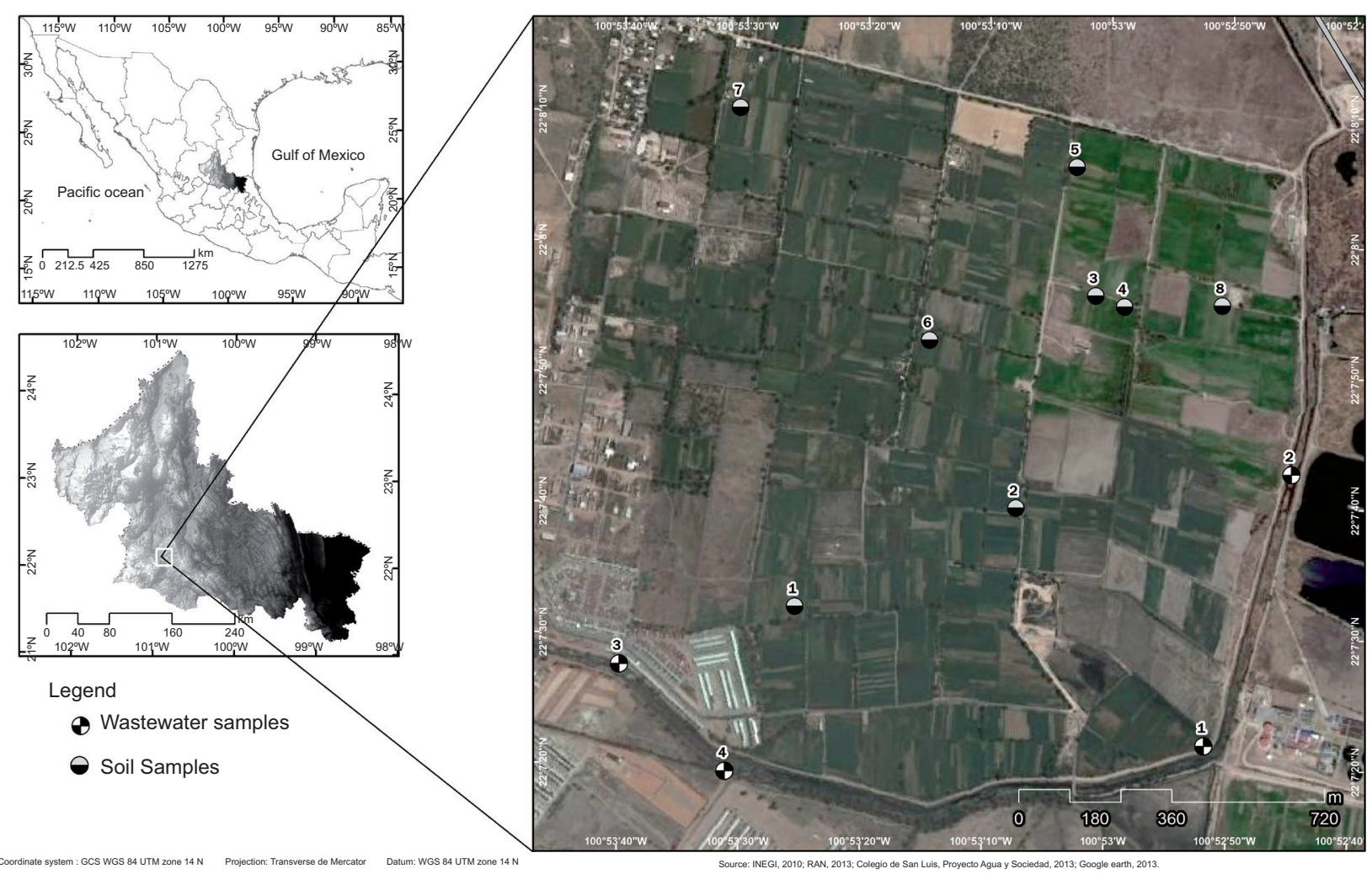

Fig. 1. Location of agricultural soil and wastewater sampling sites: Rancho la Libertad ejido and Españita River, San Luis Potosí, Mexico

30-60 cm deep samples were obtained. The following cations were determined: sodium $\left(\mathrm{Na}^{+}\right)$, calcium $\left(\mathrm{Ca}^{2+}\right)$, magnesium $\left(\mathrm{Mg}^{2+}\right)$, potassium $\left(\mathrm{K}^{+}\right)$, as well as anions: nitrate $\left(\mathrm{NO}_{3}{ }^{-}\right)$, phosphate $\left(\mathrm{PO}_{4}\right)$, chloride $\left(\mathrm{Cl}^{-}\right)$and calcium carbonate $\left(\mathrm{CaCO}_{3}\right)$ from solutions in the water quality laboratory at Centro Interamericano de Recursos del Agua (CIRA).

To assess soil fertility, SOM contents and cation exchange capacity (CEC) were determined. Texture was measured to assess cation and anion retention, as well as adsorption capacities as functions of clay and sandy contents. The $\mathrm{pH}$ and EC were obtained from soil solutions as per official guidelines (SEMARNAT 2000).

For SOM measurements an "organic carbon digestor" was used. Texture determination was made following the Bouyoucos method (SEMARNAT 2000) and a 0-60 scale Bouyoucos hydrometer. To determine and classify soil sodicity and alkalinity as a function of soil water infiltration or retention capacities, a sodium-adsorption relation (SAR) was calculated based on $\mathrm{Na}, \mathrm{Mg}$ and $\mathrm{Ca}$ concentrations observed in extracts in each sample.
A second sampling was carried out down two soil profiles of the same wastewater-irrigated area (Fig. 1) to characterize organic matter and to observe more accurately its evolution by sampling smaller sequential profile segments than the previous samples. From the first profile, samples were obtained every $10 \mathrm{~cm}$ until reaching the $60 \mathrm{~cm}$ depth. The second profile was divided in three portions at depths $0-15 \mathrm{~cm}$, $15-30 \mathrm{~cm}$ and $30-60 \mathrm{~cm}$. Nine samples were obtained in total, they were air-dried, homogenized, ground manually and passed through a (Ø2 mm) sieve.

Official guidelines (SEMARNAT 2000) were followed to determine: soil $\mathrm{pH}$ and $\mathrm{EC}$, both measured in a soil/water 1:1 mix; CEC, and soil organic carbon (SOC) via digestion in a carbon analyzer, and texture via the hydrometer method.

\section{Liquid extract for soil DOM characterization}

Moist soil (4 g) was mixed into water $(40 \mathrm{~mL})$ in a $50 \mathrm{~mL}$ centrifugation tube to obtain two $1: 10(\mathrm{w} / \mathrm{v})$ extracts. The suspension was agitated horizontally for two hours at $20^{\circ} \mathrm{C}$ and then centrifuged (500 rpm) 
for $15 \mathrm{~min}$, the supernatant was filtered using nitrocellulose membranes (Ø $0.45 \mu \mathrm{m})$ and a vacuum filtration system (Chen et al. 2003, Fuentes-Rivas et al. 2015). COD was obtained from the soil extracts.

\section{Fluorescence analysis}

The wastewater samples and liquid soil extracts were diluted to a $2 \mathrm{mg} / \mathrm{L} \mathrm{COD}$ concentration by adding deionized water of high pressure liquid chromatography (HPLC)-grade. The wastewater samples were acidified with $\mathrm{HCl}$ to $\mathrm{pH} 3$, to minimize metal complexation with dissolved organic carbon (Chen et al. 2003, Drewes et al. 2006) and to allow the scanning for each sample. The analyses of moist soil extracts were performed without $\mathrm{pH}$ alteration (Chen et al. 2003, Fuentes-Rivas et al. 2015). Fluorescence spectra were obtained with a LS55 Perkin Elmer spectrofluorometer using a 150-watt xenon lamp as an excitation source and the Winlab software for automated control.

The sample characterization yielded 45 individual synchronized emission spectra at $250-600 \mathrm{~nm}$ emission wavelengths $\left(\lambda_{\mathrm{em}}\right)$ at $5 \mathrm{~nm}$ intervals and recovered at 200-450 $\mathrm{nm}$ excitation wavelengths $\left(\lambda_{\text {exc }}\right)$. Scanning velocity/speed was $1500 \mathrm{~nm} / \mathrm{min}$ and generation time of the excitation-emission matrix (EEM) was 25 min approximately.

Along with the analyses of extracts, the spectrum of HPLC-grade deionized water was obtained. This blank was subtracted from all spectra to get the corrected spectrum of each sample (Chen et al. 2003). This technique allowed for synchronized excitationemission scans and the resultant was an excitationemission matrix (EEM) (Chen et al. 2003).

The EEM permits the analyses of spectral properties and thereby identification of the components of an unknown mixture of fluorophores. It uses multiple $\lambda_{\text {em }}$ and $\lambda_{\text {exc }}$ with different intensities to find the total luminescence (Boehme et al. 2004). Integration under the EEM volume used five excitation-emission regions (Chen et al. 2003).

\section{RESULTS AND DISCUSSION}

\section{Wastewater physical and chemical characteriza- tion (Españita river collector)}

In situ and laboratory wastewater parameters (Table I) showed $\mathrm{pH}$ between 6.8-8.5, low dissolved oxygen (DO) and negative oxidation-reduction potential (ORP) (between -192.3 and -305.2), which are consistent with industrial discharges, denoting reduction conditions. The latter explains the low concentrations of phosphate, sulfate and oxidized species of nitrogen like nitrates and nitrites. Electrical conductivity (EC) values varied from $1062 \mu \mathrm{S} / \mathrm{cm}$ to $2953 \mu \mathrm{S} / \mathrm{cm}$ indicating high salinity, which along with the SAR values (4.4-15.4), place wastewater in $\mathrm{C} 3 \mathrm{~S} 1, \mathrm{C} 3 \mathrm{~S} 2$ and $\mathrm{C} 4 \mathrm{~S} 1$ categorized by the US Salinity Laboratory as high-very high salinity and medium to low sodicity hazard, thereby limiting their use.

The presence of nitrogen species in water, such as ammonia, are indicative of partial organic matter degradation. Ammonium concentrations reported for the analyzed water are higher than those found for nitrite and nitrate (Table II). Nitrite concentrations decrease along the Españita river, while nitrate remains constant and even increases eleven fold, in the last stretch, to reach $11.0 \mathrm{mg} / \mathrm{L}$. This agrees with the fact that nitrate is the most stable form of nitrogen in aerated waters (Metcalf and Eddy 2003). Nitrogen content in urban wastewater is most often given by domestic discharges dominated by organic and ammoniacal nitrogen with few other nitrogen species. Normally, domestic wastewater has ammoniacal nitrogen $\left(\mathrm{N}-\mathrm{NH}_{4}{ }^{+}\right)$in a concentration of $12-50 \mathrm{mg} / \mathrm{L}$ (Metcalf and Eddy 2003). However, in the study area the concentration was $5.4 \mathrm{mg} / \mathrm{L}$ (Table II). The latter could be explained by the mixture of domestic and industrial water (in a higher proportion) of the residual water used in this study. Nevertheless, despite the low nitrogen content, it is necessary to use wastewater as an irrigation resource to

TABLE I. PHYSICALAND CHEMICAL CHARACTERISTICS OF WASTEWATER, ESPAÑITA RIVER COLLECTOR

\begin{tabular}{lcccccccc}
\hline Sample & $\mathrm{T}\left({ }^{\circ} \mathrm{C}\right)$ & $\mathrm{pH}$ & $\mathrm{TDS}(\mathrm{g} / \mathrm{L})$ & $\begin{array}{c}\mathrm{DO} \\
(\%)\end{array}$ & $\begin{array}{c}\mathrm{COD} \\
(\mathrm{mg} / \mathrm{L})\end{array}$ & $\begin{array}{c}\mathrm{EC} \\
(\mu \mathrm{S} / \mathrm{cm})\end{array}$ & SAR & $\begin{array}{l}\text { ORP } \\
(\mathrm{mV})\end{array}$ \\
\hline $1^{\circ}$ Españita river & 21.5 & 6.8 & 2.1 & 12.3 & 1690.0 & 2953.0 & 15.4 & -305.2 \\
$2^{\circ}$ Españita river & 22.0 & 6.8 & 1.6 & 36.4 & 1307.0 & 2360.0 & 8.90 & -252.0 \\
$3^{\circ}$ Españita river & 18.7 & 8.5 & 0.9 & 10.2 & 317.0 & 1285.0 & 4.40 & -192.3 \\
$4^{\circ}$ Colector industrias I & 25.8 & 6.9 & 1.8 & 16.6 & 2022.0 & 2768.0 & 11.9 & -220.3 \\
$5^{\circ}$ Españita river & 20.7 & 7.6 & 0.75 & 10.7 & 749.0 & 1062.0 & 4.70 & -207.0 \\
\hline
\end{tabular}

$\mathrm{T}=$ temperature, $\mathrm{DO}=$ dissolved oxygen, $\mathrm{TDS}=$ total dissolved solids, $\mathrm{COD}=$ chemical oxygen demand, $\mathrm{EC}=$ electric conductivity, $\mathrm{SAR}=$ sodium-adsorption relation, $\mathrm{ORP}=$ oxidation-reduction potential 
TABLE II. CHEMICAL CHARACTERISTICS OF WASTEWATER, ESPAÑITA RIVER COLLECTOR

\begin{tabular}{lccccc}
\hline Sample & $\begin{array}{c}\mathrm{Cl}^{-} \\
(\mathrm{mg} / \mathrm{L})\end{array}$ & $\begin{array}{c}\mathrm{SO}_{4}{ }^{2-} \\
(\mathrm{mg} / \mathrm{L})\end{array}$ & $\begin{array}{c}\mathrm{NO}_{2}{ }^{-} \\
(\mathrm{mg} / \mathrm{L})\end{array}$ & $\begin{array}{c}\mathrm{NO}_{3}{ }^{-} \\
(\mathrm{mg} / \mathrm{L})\end{array}$ & $\begin{array}{c}\mathrm{NH}_{4}{ }^{+} \\
(\mathrm{mg} / \mathrm{L})\end{array}$ \\
\hline $1^{\circ}$ Españita river & 14.8 & 39.0 & 7.00 & 0.0 & 5.36 \\
$2^{\circ}$ Españita river & 25.7 & 69.0 & 0.12 & 1.0 & 0.40 \\
$3^{\circ}$ Españita river & 22.4 & 7.0 & 0.35 & 1.0 & 0.99 \\
$4^{\circ}$ Colector Industrias I & 7.9 & 6.0 & 0.00 & 1.0 & 1.23 \\
$5^{\circ}$ Españita river & 8.0 & 21.0 & 0.00 & 11.0 & 1.26 \\
\hline
\end{tabular}

compensate the demand for water destined for agricultural activity in the area.

Wastewater organic matter reported as COD values (317-2020 $\mathrm{mg} / \mathrm{L} \mathrm{COD),} \mathrm{was} \mathrm{higher} \mathrm{than} \mathrm{the}$ most often reported and up to two orders of magnitude higher than the reported in irrigation wastewater (20 mg/L COD) (Bernier et al. 2013). Wastewater organic matter additions (30-50 $\mathrm{mg} / \mathrm{L}$ COD) to soils containing up to $48 \%$ of organic matter (OM) would not induce significant physical and chemical changes in soil (Brzezinska et al. 2011). High wastewater DOM levels in our samples when compared to other studies, could contribute with high SOM, therefore modifying the soil's fertility.

\begin{abstract}
Physical and chemical characteristics of the agricultural soil studied (Rancho Viejo)

EC (78.62-384.65 $\mu \mathrm{S} / \mathrm{cm})$ and SAR (0.76-1.53) in the soil profiles showed no salinity or sodicity conditions (Table III), but rather normal soils as per the USDA classification (USDA 2015). This seemed linked to adequate drainage given by sandy-loam and loamy-sand textures, which may considerably diminish the effects of salinity added by wastewater. This was favorable considering that irrigation is linked to salt concentrations in (semi) arid agricultural areas (Walker and Lin 2008). In the valley of San Luis Potosi there is low rainfall, the annual average is $358 \mathrm{~mm} /$ year and the actual evapotranspiration is
\end{abstract}

TABLE III. PHYSICAL AND CHEMICAL PROPERTIES OF AGRICULTURAL SOIL SAMPLES, RANCHO LA LIBERTAD, SAN LUIS POTOSÍ

\begin{tabular}{|c|c|c|c|c|c|c|c|c|c|c|}
\hline \multirow[b]{2}{*}{ Sample } & \multirow[b]{2}{*}{$\mathrm{pH}$} & \multirow[b]{2}{*}{$\begin{array}{c}\mathrm{EC} \\
(\mu \mathrm{S} / \mathrm{cm})\end{array}$} & \multirow[b]{2}{*}{ SAR } & \multirow{2}{*}{$\begin{array}{c}\mathrm{N}_{-} \mathrm{NO}_{3}{ }^{-} \\
(\mathrm{mg} / \mathrm{L})\end{array}$} & \multirow[b]{2}{*}{$\begin{array}{c}\mathrm{OC} \\
(\mathrm{g} / \mathrm{kg})\end{array}$} & \multirow[b]{2}{*}{$\begin{array}{l}\mathrm{OM} \\
(\%)\end{array}$} & \multirow{2}{*}{$\begin{array}{c}\mathrm{CEC} \\
(\mathrm{cmol} / \mathrm{kg})\end{array}$} & \multicolumn{3}{|c|}{ Texture } \\
\hline & & & & & & & & $\begin{array}{c}\text { Sand } \\
(\%)\end{array}$ & $\begin{array}{l}\text { Silt } \\
(\%)\end{array}$ & $\begin{array}{l}\text { Clay } \\
(\%)\end{array}$ \\
\hline $1 \mathrm{~A}$ & 6.89 & 384.65 & 1.27 & 9.00 & 4.13 & 7.10 & 13.18 & 65.8 & 4.0 & 30.2 \\
\hline $1 \mathrm{~B}$ & 8.08 & 194.02 & 1.07 & 8.57 & 1.43 & 2.46 & 12.36 & 63.8 & 16.0 & 20.2 \\
\hline $2 \mathrm{~A}$ & 6.74 & 109.42 & 1.53 & 3.70 & 2.01 & 3.45 & 14.21 & 73.8 & 4.0 & 22.2 \\
\hline $2 \mathrm{~B}$ & 7.05 & 95.88 & 1.33 & ND & 2.28 & 3.92 & 14.02 & 73.8 & 10.0 & 16.2 \\
\hline $3 \mathrm{~A}$ & 6.94 & 124.49 & 1.38 & 5.02 & 2.67 & 4.60 & 9.95 & 57.8 & 14.0 & 28.2 \\
\hline $3 \mathrm{~B}$ & 7.40 & 94.75 & 1.24 & ND & 1.08 & 1.85 & 10.32 & 58.6 & 14.0 & 27.4 \\
\hline $4 \mathrm{~A}$ & 7.13 & 113.57 & 1.16 & 5.57 & 3.11 & 5.35 & 13.87 & 68.6 & 10.0 & 21.4 \\
\hline $4 \mathrm{~B}$ & 7.40 & 106.03 & 1.06 & ND & 1.00 & 1.71 & 12.88 & 68.6 & 10.0 & 21.4 \\
\hline $5 \mathrm{~A}$ & 6.44 & 191.10 & 1.07 & 3.93 & 1.23 & 2.11 & 10.15 & 58.6 & 14.0 & 27.4 \\
\hline $5 \mathrm{~B}$ & 7.49 & 78.62 & 0.83 & ND & 0.00 & 0.00 & 10.81 & 74.6 & 6.0 & 19.4 \\
\hline $6 \mathrm{~A}$ & 6.25 & 187.82 & 0.85 & 8.45 & 5.18 & 8.92 & 14.02 & 78.6 & 2.0 & 19.4 \\
\hline $6 \mathrm{~B}$ & 7.34 & 108.11 & 0.83 & ND & 0.91 & 1.56 & 13.18 & 76.4 & 2.0 & 21.6 \\
\hline $7 \mathrm{~A}$ & 7.36 & 229.32 & 0.81 & 4.37 & 2.19 & 3.77 & 14.79 & 82.4 & 0.0 & 17.6 \\
\hline $7 \mathrm{~B}$ & 8.58 & 173.63 & 0.86 & ND & 1.03 & 1.77 & 11.20 & 76.4 & 0.0 & 23.6 \\
\hline $8 \mathrm{~A}$ & 8.30 & 264.26 & 0.89 & 4.92 & 1.82 & 3.13 & 13.81 & 82.4 & 4.0 & 13.6 \\
\hline $8 \mathrm{~B}$ & 8.89 & 374.56 & 0.76 & ND & 1.01 & 1.73 & 14.06 & 78.4 & 4.0 & 17.6 \\
\hline
\end{tabular}

$\mathrm{ND}=$ not determinated, $\mathrm{EC}=$ electric conductivity, $\mathrm{SAR}=$ sodium-adsorption relation, $\mathrm{N}-\mathrm{NO}_{3}{ }^{-}=$nitrogen as a nitrate, $\mathrm{OC}=$ organic carbon, $\mathrm{OM}=$ organic matter, $\mathrm{CEC}=$ cation exchange capacity 
$347 \mathrm{~mm} /$ year, which correspond to $97.5 \%$ of total precipitation (Carranco-Lozada et al. 2016).

Predominant agricultural soils in the study area are haplic xerosols with low SOM content, typical of (semi) arid areas. The predominant crop was alfalfa (Medicago sativa), under furrow irrigation. Maximum SOM was 8.93 and $7.12 \%$, at a $0-30 \mathrm{~cm}$ depth. Modal values were less than $4.6 \%$ and lower values were in the $30-60 \mathrm{~cm}$ soil layer. Sample 6 had both the highest topsoil and one of the lowest deep-layer SOM values (Table III). SOM values below $6 \%$ (SarabiaMeléndez et al. 2011) and even $2 \%$ (Salazar-Ledesma 2011) are common in the region. The topsoil SOM values were similar to those reported elsewhere (Filip and Kubát 2001, Jüeschke et al. 2008).

The values reflect the low SOM content in soils analyzed. Some studies considered values between $1 \%$ and $6 \%$ as normal (Chen et al. 2010). Fassbender (1982) point out that the surface horizons of agricultural soils have values between 0.1 and $10 \%$ of SOM and tend to diminish in B horizons. Bot and Benites (2005) indicate that most soils contain between $2 \%$ and $10 \%$ of SOM. According to Mexican guidelines (SEMARNAT 2000), our samples are classified as medium to very low-SOM with values lower than $3.5 \%$, although some samples can be classified as high-SOM.

In agricultural environments, the low clay content (13.6 \% - 30.2 \%) may be linked to the low SOM in the predominantly loamy-sand and sandy-loam textures of the study area (Table III). Nadav et al. (2013) report $1.4 \% \mathrm{OM}$ in soil with $86 \%$ sand. Values of $3.3 \mathrm{~g} / \mathrm{kg}$ organic carbon (OC) in soils containing $80 \%$ sand, rise to $11 \mathrm{~g} / \mathrm{kg}$ in soils with $62 \%$ clay (Bernier 2013). SOM augments with clay content because clay protects SOM molecules, thereby slowing down decomposition and impeding further mineralization by soil microorganisms (Bot and Benites 2005, Mavi et al. 2012). Overall, SOM in a fine-texture soil is two to four times higher than in a coarse texture soil under similar climatic conditions (Prasad and Power 1997, Bot and Benites 2005). In the study area, values below $1.7 \%$ $\mathrm{OM}$ in regosols have been reported (Ibarra-Castillo et al. 2007). This is because soils generated from basalt materials are more fertile than those originating from granite material or riolites (Bot and Benites 2005).

$\mathrm{CEC}$ also reflects SOM content (Bot and Benites 2005) and texture. CEC values were $9.95-14.79 \mathrm{cmol} / \mathrm{kg}$ (Table III), which are low values according to the Mexican guidelines (SEMARNAT 2000), similar to those found in a nearby area (Salazar-Ledesma 2011). CEC was comparable to $8.6-12.6 \mathrm{cmol} / \mathrm{kg}$ values in $80 \%$ sand soils, while $70.3 \mathrm{cmol} / \mathrm{kg} \mathrm{CEC} \mathrm{was} \mathrm{found}$ in $65 \%$ clay soils, both of which were soils irrigated with treated wastewater (Bernier et al. 2013). Wastewater-irrigated soils have recorded $9.8 \mathrm{cmol} / \mathrm{kg} \mathrm{CEC}$ in Spain $(52 \mathrm{mg} / \mathrm{L} \mathrm{COD}$; Morugan-Coronado et al. 2011 ) and $65.6 \mathrm{cmol} / \mathrm{kg}$ in clay soils (Bhardwaj et al. 2007). Mavi et al. (2012), also reported 5.2-14.7 $\mathrm{cmol} / \mathrm{kg}$ CEC in soils containing $85 \%$ sand or more.

The values reported here result from high sand and low SOM contents. Wastewater COD did not lead to a SOM increment. This is similar to $1 \%$ organic matter increments in wastewater irrigated soils in Pennsylvania (Walker and Lin 2008) and $35.3 \mathrm{~g} / \mathrm{kg}$ SOM in soils with higher clay contents irrigated with $(86.8 \mathrm{mg} / \mathrm{L}$ BOD) treated wastewater (Bhardwaj et al. 2007). Due to the texture characteristics in the analyzed soil, high content of sand and low organic matter content allow good drainage of residual water, which explains the high permeability of the soil and the low residence time of DOM.

\section{Physical and chemical characteristics of the agri- cultural soil profiles studied (Rancho la Libertad)}

The soil profile $\mathrm{pH}$ was $8.39-9.24$, the $0-20 \mathrm{~cm}$ layer was in the slightly alkaline range (7.4-8.5) while the 20-60 $\mathrm{cm}$ layer was highly alkaline $(\mathrm{pH}>8.5$; Table IV). EC either augmented with depth (sample MS1: 247.81-317.70 $\mu \mathrm{S} / \mathrm{cm}$ ) or diminished (sample MS2: 455.52-283.22 $\mu \mathrm{S} / \mathrm{cm}$; Fig. 2). EC value ranges were low in both depths, denoting a non-saline soil. Bot and Benites (2005), report that salinity and extremes in soil $\mathrm{pH}$ (acid or alkaline) result in poor biomass production and thus, in reduced additions of organic matter to the soil, consistent with data reported in this study.

OC was $0.218-0.233 \mathrm{~g} / \mathrm{kg}$ in the first $10 \mathrm{~cm}$ and diminished with soil depth. The largest descent occurred at $60 \mathrm{~cm}$ depth with $0.05 \mathrm{~g} / \mathrm{kg} \mathrm{OC}$, reaching $24 \%$ of the value at the surface (Fig. 2). These descents concur with other studies (Friedel et al. 2000, Jüeschke et al. 2008). Considering SOM, the OC represents $58 \%$ (Thompson and Troeh 1988). In the study area, the OC values were very low. SOM in MS1 was $0.4017 \%$ (at a $0-15 \mathrm{~cm}$ depth), $0.3051 \%$ (at 15-30) and 0.148\% (at 30-60), while in MS2 it was $0.277 \%$ (at $0-10), 0.263 \%$ (at 10-20), $0.299 \%$ (at 20-30), 0.172\% (at 30-40), 0.120\% (at 40-50) and $0.086 \%$ (at 50-60). The $\mathrm{pH}$ affects humus formation, either in strongly acid or highly alkaline soils, the growing conditions for microorganisms are poor, resulting in low levels of biological oxidation of organic matter (Bot and Benites 2005).

The distribution of particle size indicated high silt and sand contents in most samples, except at 15 $\mathrm{cm}$ depth, where sand percentage was higher. SOM 
TABLE IV. PHYSICAL AND CHEMICAL CHARACTERISTICS OF SOIL SAMPLES (MS1, MS2) AT RANCHO LA LIBERTAD, SAN LUIS POTOSÍ

\begin{tabular}{|c|c|c|c|c|c|c|c|}
\hline \multirow{2}{*}{$\begin{array}{l}\text { Depth } \\
(\mathrm{cm})\end{array}$} & \multirow[t]{2}{*}{$\mathrm{pH}$} & \multirow{2}{*}{$\begin{array}{c}\mathrm{EC} \\
(\mu \mathrm{S} / \mathrm{cm})\end{array}$} & \multirow{2}{*}{$\begin{array}{c}\text { CEC } \\
(\mathrm{Cmol} / \mathrm{Kg})\end{array}$} & \multirow{2}{*}{$\begin{array}{c}\mathrm{OC} \\
(\mathrm{g} / \mathrm{Kg})\end{array}$} & \multicolumn{3}{|c|}{ Texture } \\
\hline & & & & & ( $\%$ clay) & (\% Silt) & (\% sand) \\
\hline \multicolumn{8}{|c|}{ MS1 } \\
\hline $0-15$ & 8.80 & 247.81 & 15.66 & $0.233 \pm 0.07$ & 10.0 & 30.0 & 60.0 \\
\hline $15-30$ & 9.14 & 244.39 & 12.54 & $0.177 \pm 0.07$ & 18.0 & 42.0 & 40.0 \\
\hline $30-60$ & 9.13 & 317.70 & 13.78 & $0.086 \pm 0.07$ & 41.0 & 46.0 & 13.0 \\
\hline \multicolumn{8}{|c|}{ MS2 } \\
\hline $0-10$ & 8.39 & 455.52 & 14.26 & $0.218 \pm 0.05$ & 11.0 & 45.0 & 44.0 \\
\hline $10-20$ & 9.17 & 296.92 & 12.29 & $0.153 \pm 0.05$ & 34.0 & 54.0 & 12.0 \\
\hline $20-30$ & 8.78 & 232.97 & 12.99 & $0.174 \pm 0.05$ & 31.0 & 65.0 & 4.0 \\
\hline $30-40$ & 9.24 & 274.08 & 12.69 & $0.100 \pm 0.05$ & 42.0 & 53.0 & 5.0 \\
\hline $40-50$ & 9.30 & 251.24 & 12.44 & $0.070 \pm 0.05$ & 38.0 & 49.0 & 13.0 \\
\hline $50-60$ & 9.07 & 283.22 & 12.55 & $0.050 \pm 0.05$ & 22.0 & 41.0 & 37.0 \\
\hline
\end{tabular}

$\mathrm{EC}=$ electric conductivity, $\mathrm{CEC}=$ cation exchange capacity, $\mathrm{OC}=$ organic carbon

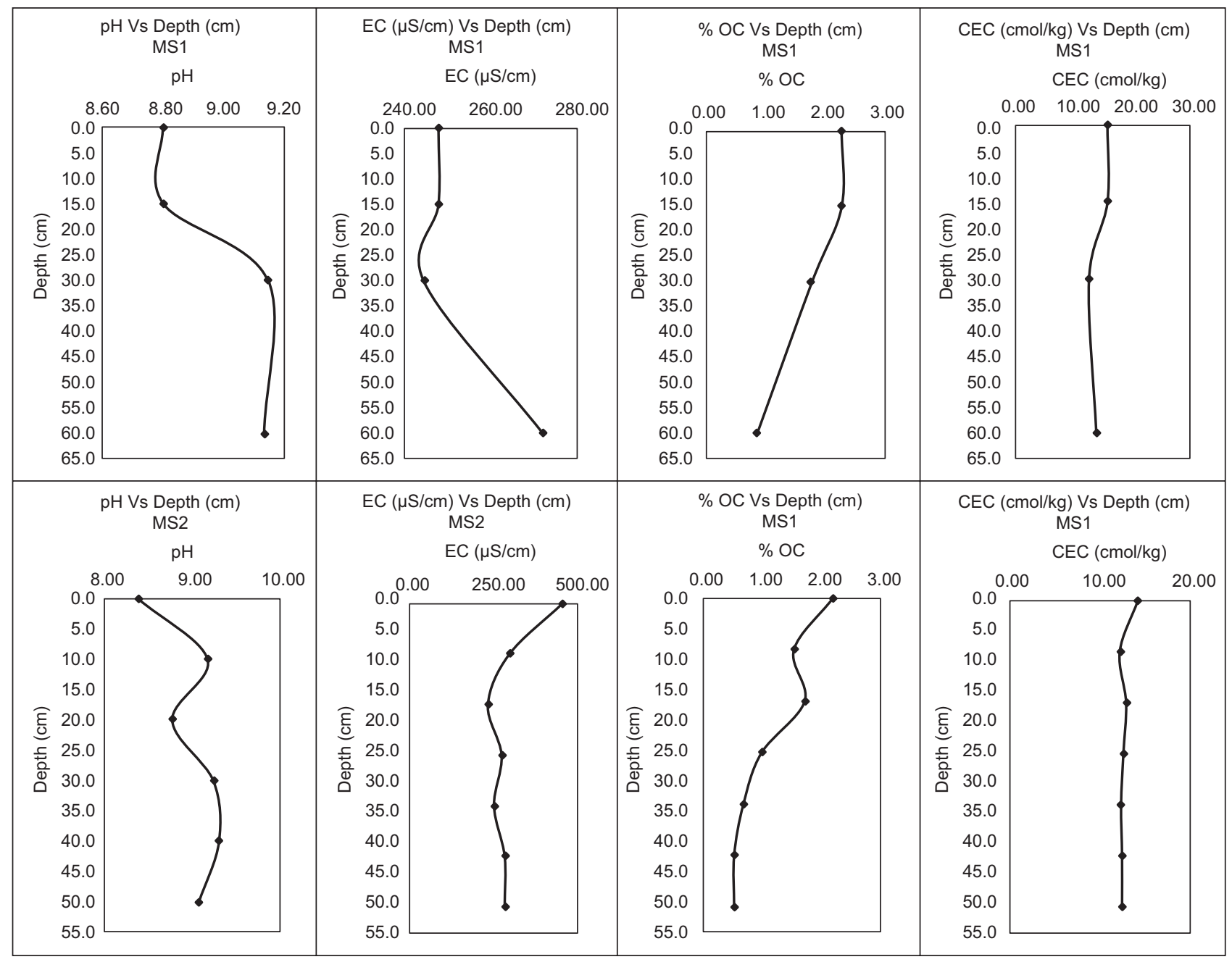

Fig. 2. Physical and chemical behavior of soil as a function of depth. Soil sample $1(\mathrm{MS} 1)$ and soil sample $2(\mathrm{MS} 2)$. EC = electric conductivity, $\mathrm{OC}=$ organic carbon, $\mathrm{CEC}=$ cation exchange capacity 

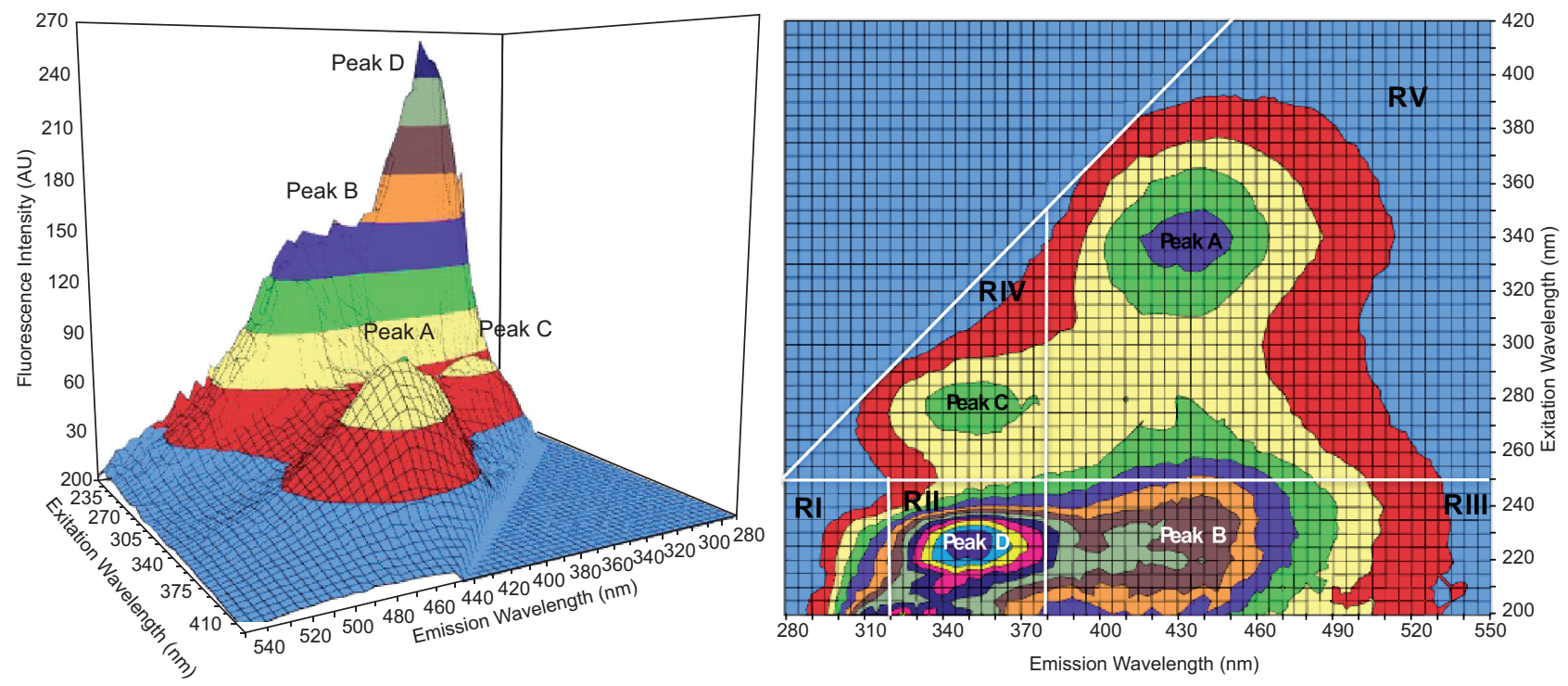

Fig. 3. a) Vertical spectrum projection, b) Horizontal spectrum projection. Five regions in fluorescence 3D spectrum, wastewater sample collected in study area. Regions I and II, aromatic proteins; region IV, bacterial degradation products; regions I, II and IV, anthropogenic organic matter; region III, fulvic acids and region V, humic acids (natural organic matter)

was characteristic of arid land sandy soils (Chen et al. 2010). This seems to suggest that DOM added by wastewater to the soil was not being retained, due to the high sand compositions in sandy-loam and loamy-sand soils, unlike the clay fraction, these do not help retain DOM. While some reports mention that DOM added by wastewater is readily degradable (Fine et al. 2002, Meli et al. 2002, Saadi et al. 2006), others find a SOM increase by a factor of 1.4 in wastewater-irrigated soils with high organic load (Kaushik et al. 2005, Álvarez-Bernal et al. 2006).

Regarding CEC, the total amount of negative charges available on the surface of soil particles was low and varied little in the soil profiles: $15.66 \mathrm{cmol} / \mathrm{kg}$ $(0-15 \mathrm{~cm}), 12.54 \mathrm{cmol} / \mathrm{kg}(15-30 \mathrm{~cm})$ and $13.78 \mathrm{cmol} / \mathrm{kg}$ $(30-60 \mathrm{~cm})$ in sample MS1, and $14.26(0-10 \mathrm{~cm}), 12.29$ $(10-20 \mathrm{~cm}), 12.99(20-30 \mathrm{~cm}), 12.69(30-40 \mathrm{~cm})$, $12.44(40-50 \mathrm{~cm})$ y $12.55 \mathrm{cmol} / \mathrm{kg}(50-60 \mathrm{~cm})$ in sample MS2 (Fig. 2). CEC depends on soil texture and SOM. Generally, CEC augments with clay and SOM content. In the soil profiles studied in this research, SOM was low because CEC could be associated with the clay fraction.

\section{D fluorescence of DOM in the soil profiles}

SOM analysis (Walkley and Black 1934) registered $0-9.83 \%$ SOM values in points $1 \mathrm{~A}-8 \mathrm{~B}$ (Table III). 3D fluorescence (Chen et al. 2003) was used to identify ADOM presence in two soil profiles corresponding to points MS1 and MS2 (Table V).
According to Chen et al. (2003), the spectrum is divided into five regions (Fig. 3b). Regions I and II correspond to aromatic proteins (anthropogenic organic matter). Region III and V, fulvic and humic acids, respectively (natural organic matter). Finally, region IV, bacterial degradation products (anthropogenic organic matter). To ensure that aromatic proteins are present in the water analyzed, the peak must be formed in regions I or II. It is possible to observe peaks in those regions, and both are associated with the presence of aromatic proteins.

The scans are performed every $5 \mathrm{~nm}$ of wavelength excitation, in the excitation-emission matrix (EEM), areas of different colors are observed, the colors are given automatically by the software to contrast the fluorescence intensity in each scan. These areas form closed polygons, similar to the contours of a topographic map (Fig. 3a). The spectrum shows the horizontal elevation projection of the EEM (Fig. 3b). As mentioned above, each region is associated with a type of DOM that can be natural or anthropogenic (Chen et al. 2003). Peaks are located on one of the five regions and, with the excitation-emission wavelength value, it is possible to know the origin.

It should be noted that applying the 3D fluorescence technique in soils is novel. Mostly in soils that are being irrigated with anthropogenic organic material, which when it is not retained in the soil profile, it can migrate into the aquifer and alter the groundwater quality. 
TABLE V. 3D FLUORESCENCE CHARACTERISTICS IN SOIL SAMPLES (MS1, MS2)

\begin{tabular}{ccccc}
\hline \multirow{2}{*}{$\begin{array}{c}\text { Depth } \\
(\mathrm{cm})\end{array}$} & \multicolumn{4}{c}{ Fluorescence intensity (Excitation/Emission(nm)) } \\
\cline { 2 - 5 } & Peak A & Peak B & Peak C & Peak D \\
\hline \multicolumn{5}{c}{ MS1 } \\
\hline $0-15$ & $80.58(320 / 417.50)$ & $117.08(245 / 434)$ & \\
$15-30$ & $63.55(320 / 417.50)$ & $97.14(245 / 380.50)$ & & \\
$30-60$ & & & $28.75(275 / 356.50)$ & $262.16(200 / 313.50)$ \\
\hline \multicolumn{5}{c}{ MS2 } \\
\\
\hline $0-10$ & $178.31(330 / 436.50)$ & $248.05(245 / 436.50)$ & \\
$10-20$ & $80.44(320 / 429.00)$ & $115.53(245 / 438.50)$ & & \\
$20-30$ & $89.17(320 / 414.50)$ & $118.58(245 / 432.00)$ & & $77.80(245 / 360.50)$ \\
$30-40$ & $27.97(320 / 419.50)$ & & & $55.81(245 / 353.50)$ \\
$40-50$ & $25.55(320 / 428.50)$ & & & \\
$50-60$ & & & & \\
\hline
\end{tabular}

The synchronized spectra showed four main fluorescence peaks (Fig. 4). Sample MS1 showed two similar peaks at $0-15$ and $15-30 \mathrm{~cm}$ depths (Table V): Peak A $\left(320_{\text {exc }} / 417_{\text {em }}\right.$ wavelengths, 85.58 and 63.55 intensities) and B (245 exc $\left./ 380-434_{\mathrm{em}}\right)$. At a $30-60 \mathrm{~cm}$ depth, a peak $C$ is observed (275exc/356em), even though the fluorescence intensity is low. Peak C was well defined in contrast to peak D (200exc/313em) at the same depth. Peaks A and B were associated to humic (region $\mathrm{V}$ ) and fulvic acids (region III) from natural DOM (Chen et al. 2003, Traversa et al. 2008, Xue et al. 2013). Peak C was related to microbial products (region IV) and peak D with aromatic proteins (region I), corresponding to anthropogenic DOM. Table $\mathbf{V}$ shows the excitation-emission wavelength values at which peaks are located on spectrum, as well as the maximum fluorescence intensity in each identified peak.

DOM in sample MS2 was related to humic acids (peak A) and fulvic acids (peak B) at a 0-30 cm depth, and aromatic proteins (peak D) at $30-60 \mathrm{~cm}$ depth. Peak A remained through the whole profile and peak B was present only at 0-30 cm depth. Peak D appeared at 30-60 cm. A shift in MS1 and MS2 spectra at $0-30 \mathrm{~cm}$ depth, absent in MS1 at $30-60 \mathrm{~cm}$, was observed at $220 \mathrm{~nm}$, the wavelength at which nitrogen absorbs light. This suggested recent fertilization (Fuentes Rivas et al. in press). If nitrogenous species concentration, such as nitrates are high, it is possible to observe a displacement in the fluorescence spectrum at $220 \mathrm{~nm}$ emission wavelength, the wavelength of nitrogen absorption, and this can be indicative of recent fertilization or organic matter mineralization.

Sample MS2 aromatic proteins at $30-60 \mathrm{~cm}$ depth (Fig. 4), were linked to higher clay content:
$42 \%$ at $30-40 \mathrm{~cm}$ and $38 \%$ at $40-50 \mathrm{~cm}$ depths. A similar high clay content (41\%) was found at $30 \mathrm{~cm}$ in sample MS1. Previous studies have established a relationship between soil texture and particulate SOM: adsorption of the latter onto the clay fraction of soil is a significant form of its preservation (Mayer and Xing, 2001, Mayer et al. 2004, Bruun et al. 2010, Clemente et al. 2011). In muddy source rocks too, most DOM concentrates in the clay fraction, but the link between DOM and clay fraction is not well understood at present (CaiJ et al. 2009, CaiJ et al. 2010, Ding et al. 2011).

According to figure 4, in the fluorescence 3D spectrum at $15 \mathrm{~cm}$ depth, only natural organic matter was observed, (regions V and III). Humic acid fluorescence intensity was higher than fulvic acid, at 30 $\mathrm{cm}$ depth. So, if at low concentrations fluorescence intensity is directly proportional to concentration, then there is a greater concentration of humic acids in $30 \mathrm{~cm}$ than at $15 \mathrm{~cm}$ deep (Fig. 4). At $60 \mathrm{~cm}$ depth, natural dissolved organic matter disappears, and it is only possible to find an anthropogenic dissolved organic matter presence (peak D), associated to microbiological degradation products. However, in figure $\mathbf{4}$ it is not possible to observe the evolution of anthropogenic dissolved organic matter in soil profile.

Fluorescence intensity is high in the first $10 \mathrm{~cm}$ (both samples), and diminishes with depth (Fig. 5). This was connected with the main influence of $\mathrm{pH}$ on fluorescence. Fluorescence intensity decreases with $\mathrm{pH}(2-3)$ while $\mathrm{pH}$ increase augments fluorescence proportionally (Zhao et al. 2010). Very low pH inhibits biological activity and thus the SOM mineralization rate. Conversely, at $\mathrm{pH}$ 6-7.2 bacteria 


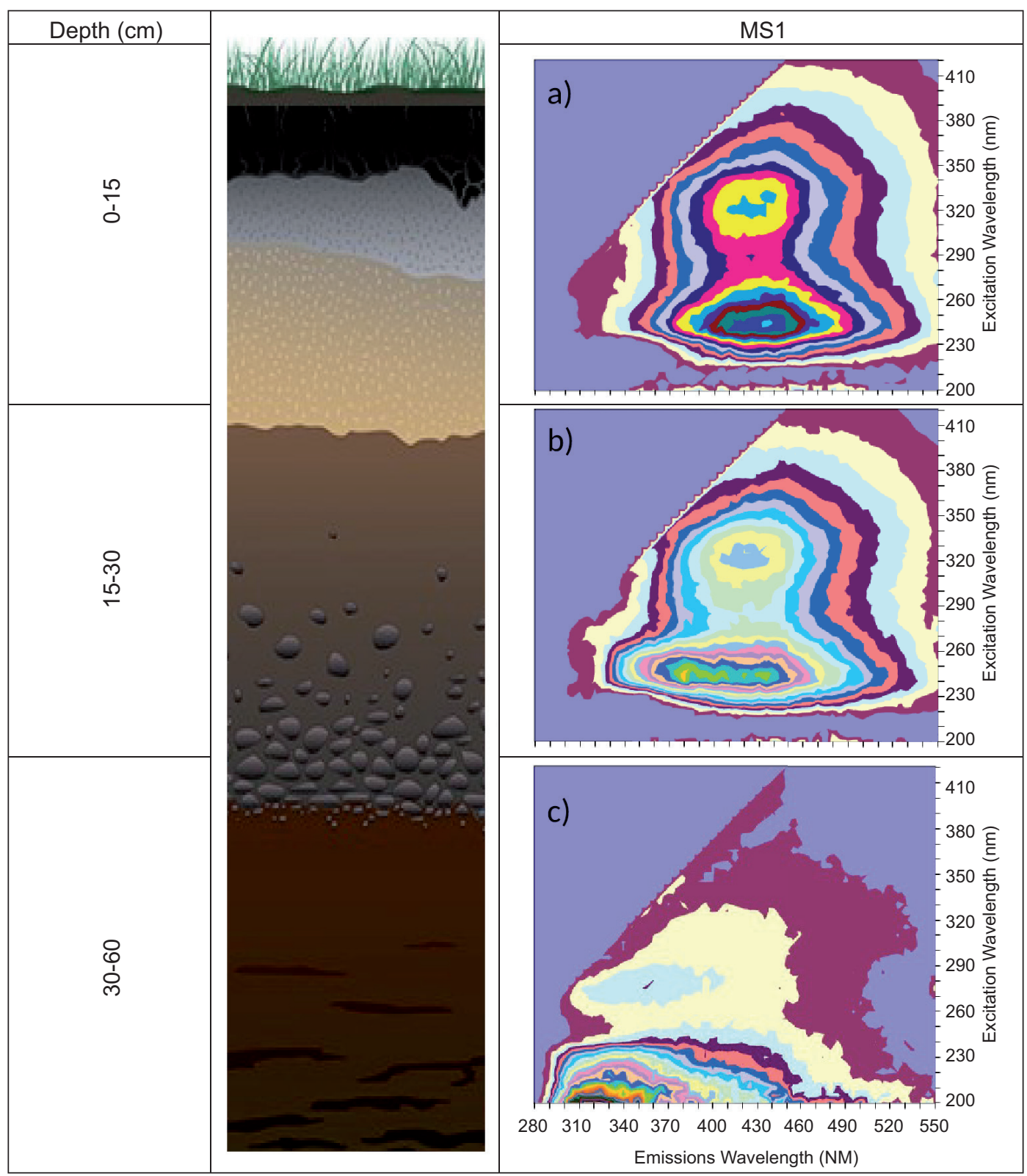

Fig. 4. Excitation-emission matrix spectra of dissolved organic matter extracted from soil samples at different depths of soil sample 1 (MS1): a) 0-15 cm, peaks A and B (natural organic matter), b) $15-30 \mathrm{~cm}$ peaks A and D (natural organic matter, anthropogenic organic matter), c) $30-60 \mathrm{~cm}$ peaks $\mathrm{C}$ and $\mathrm{D}$ (anthropogenic organic matter)

degrade SOM more actively. Here, soil was slightly alkaline in the first $10 \mathrm{~cm}(\mathrm{pH} 8.0)$ and highly alkaline deeper ( $\mathrm{pH} 9.0)$, suggesting low microbial activity (Mavi 2012). Higher clay contents and low microbial activity combined are needed to preserve soil DOM.

In the second soil profile, MS2 sample (Fig. 5), it is possible to observe the dissolved organic matter evolution. For example, at the first $20 \mathrm{~cm}$ depth, humic and fulvic acids are observed, whereas from 20 to $60 \mathrm{~cm}$, additional humic acids and aromatic proteins are present too (spectrum region II). Unlike humic acids, fluorescence intensity of aromatic proteins increases with depth, being greater at $40 \mathrm{~cm}$, which is the depth with higher clay content. So it is possible to infer that the soil studied does not act as a retention barrier from organic pollutants from wastewater. The latter because the anthropogenic organic 


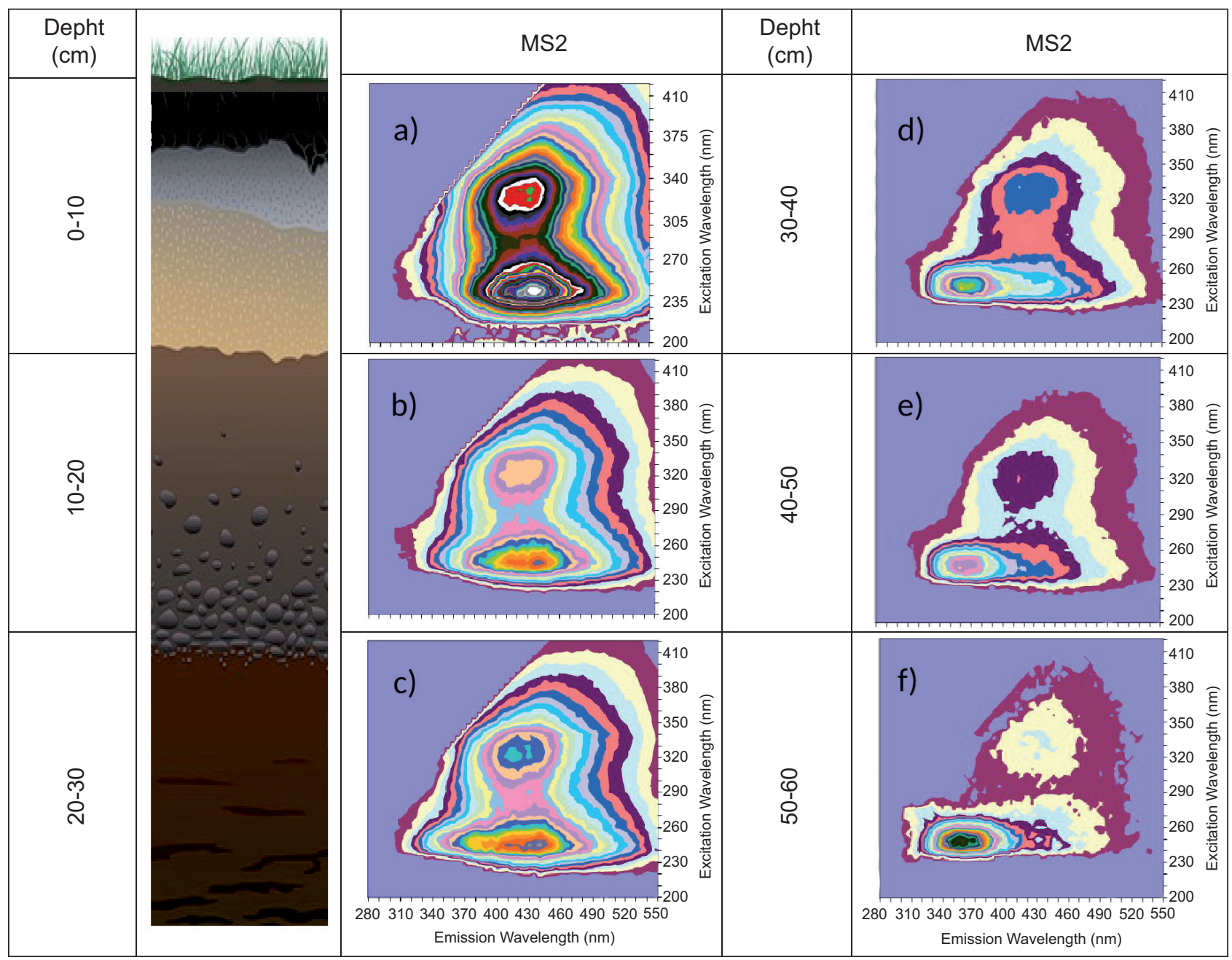

Fig. 5. Excitation-emission matrix spectra of dissolved organic matter extracted from soil samples at different depths of soil sample 2 (MS2): a) 0-10 cm, peaks A, humic acids (region V) and B, fulvic acids (region III), b) $10-20 \mathrm{~cm}$, peaks A and B, natural organic matter, c) 20-30 cm, peaks A and D, aromatic proteins (region I), d) peaks A and D, e) peaks A and D, f) peaks A and D

matter moves along the soil profile and, although their retention by clay is observed, the amount of organic matter entering is even greater. As mentioned in the beginning, the fluorescence technique is performed at $2 \mathrm{mg} / \mathrm{L}$ COD concentration. So, it is possible that organic compounds can reach the aquifer and alter the groundwater quality.

\section{CONCLUSION}

In the vicinity of discharges into the Españita river collector, $\mathrm{pH}$ was slightly acid, dissolved oxygen was low and redox potential was negative. This reducing conditions may explain the low concentrations of phosphates, sulfates and nitrogenous species such as nitrates.
Electric conductivity $(1062-2953 \mu \mathrm{S} / \mathrm{cm})$, indicative of high salinity, combined with the sodiumabsorption relation (4.40-15.4) implied high to very high salinity hazard, and medium to low sodicity hazard, thereby limiting wastewater use.

The wastewater had concentrations up to $5.4 \mathrm{mg} / \mathrm{L}$ $\mathrm{NH}_{4}{ }^{+}$and $11.0 \mathrm{mg} / \mathrm{L} \mathrm{NO}_{3}{ }^{-}$. These nitrogen contents have driven its use for agricultural purposes in the study area. The addition of organic matter was substantial with values up to $2020 \mathrm{mg} / \mathrm{L}$ COD. Nevertheless, it is not reflected in the content of organic matter in the soil $(0-8.92 \%)$.

The agricultural soil under analysis did not show salinity or sodicity conditions and so it was classified as normal. The texture was sandy loam or loamy sand, which provided adequate drainage conditions. Soil organic carbon and cation exchange 
capacity were very low, characteristic of sandy arid land soils.

3D fluorescence spectra of the soil profiles evidenced natural organic matter, humic and fulvic acids, as well as anthropogenic organic matter, aromatic proteins and microbial degradation products.

The anthropogenic dissolved organic matter was only observed in the profile samples with highest clay contents.

A majority of fluorescence spectra showed a shift between 200 and $220 \mathrm{~nm}$, possibly due to the interference of nitrogenous species from irrigation wastewater or recent soil fertilization.

3D fluorescence ascertained the depth at which anthropogenic dissolved organic matter was retained, it also highlighted its evolution in the soil profile.

The soil does not act as a retention barrier of dissolved organic pollutants from wastewater.

\section{ACKNOWLEDGMENTS}

This study was funded by Instituto Potosino de Investigación Científica y Tecnológica (IPICYT) and Universidad Autónoma del Estado de México - Centro Interamericano de Recursos del Agua (CIRA).

\section{REFERENCES}

Abedi-Koupai J., Mostafazadeh-Fard B., Afyuni M. and Bagheri M. R. (2006). Effect of treated wastewater on soil chemical and physical properties in an arid region. Plant Soil Environ. 52 (8), 335-344.

Akagi J., Zsolnay A. and Bastida F. (2007). Quantity and spectroscopic properties of soil dissolved organic matter (DOM) as a function of soil sample treatments: air-drying and pre-incubation. Chemosphere 69 (7), 1040-1046.

DOI: 10.1016/j.chemosphere.2007.04.036

Álvarez-Bernal D., Contreras-Ramos S. M., Trujillo-Tapia N., Olalde-Portugal V., Frías-Hernández J. T. and Dendooven L. (2006). Effects of tanneries wastewater on chemical and biological soil characteristics. Appl. Soil Ecol. 33 (3), 269-277.

DOI: $10.1016 /$ j.apsoil.2005.10.007

Álvarez R. and Steinbach H. (2006). Asociación entre el nitrógeno del suelo y el rendimiento de los cultivos. In: Materia orgánica: valor agronómico y dinámica en suelos pampeanos. (R. Álvarez, Ed.). Facultad de Agronomía-UBA, Buenos Aires, Argentina, pp 79-92.

Bernier M. H., Levy G. J., Fine P. and Borisover M. (2013). Organic matter composition in soils irrigated with treated wastewater: FT-IR spectroscopic analysis of bulk soil samples. Geoderma 209 (210), 233-240. DOI: 10.1016/j.geoderma.2013.06.017

Bhardwaj A. K., Goldstein D., Azenkot A. and Levy G. J. (2007). Irrigation with treated wastewater under two different irrigation methods: Effects on hydraulic conductivity of a clay soil. Geoderma 140 (1-2), 199-206. DOI: 10.1016/j.geoderma.2007.04.003

Boehme J., Coble P., Conmy R. and Stovall-Leonard A. (2004). Examining CDOM fluorescence variability using principal component analysis: seasonal and regional modeling of three-dimensional fluorescence in the Gulf of Mexico. Mar. Chem. 89 (1-4), 3-14.

DOI: 10.1016/j.marchem.2004.03.019

Bot A. and Benites J. (2005). The importance of soil organic matter: Key to drought-resistant soil and sustained food production. FAO Soils Bulletin 80, 1-95.

Brzezińska M., Sokołowska Z., Alekseeva T., Alekseev A., Hajnos M. and Szarlip P. (2011). Some characteristics of organic soils irrigated with municipal wastewater. Land Degrad. Dev. 22 (6), 586-595.

DOI: $10.1002 / \mathrm{ldr} .1036$

Brooks D. M., Pando-Vásquez L. and Ocmin-Petit A. (1999). Comparative life history of cotingas in the northern Peruvian Amazon. Ornitol Neotrop. 10, 193-206.

Bruun T. B., Elberling B. and Christensen B. T. (2010). Lability of soil organic carbon in tropical soils with different clay minerals. Soil Biol. Biochem. 42 (6), 888-895.

DOI: $10.1016 /$ j.soilbio.2010.01.009

Cai J. G., Lu L., Ding F. and Fan F. (2009). Significance of interaction between soluble organic matter and clay minerals in muddy source rocks (in Chinese). J. Tongji Univ. (Nat. Sci.). 37, 1679-1684.

Cai J. G., Lu L. F., Song M. S., Ding F., Bao Y. J. and Fan F. (2010). Characteristics of extraction of organo-clay complexes and their significance to petroleum geology. Oil Gas Geol. 31 (3), 300-308.

Carranco-Lozada S., Ramos-Leal J., Almanza-Tovar O. and Morán-Ramírez J. (2016). Balance hidrológico superficial del Valle de San Luis Potosí. In: Condiciones hidrogeoquímicas y explotación del sistema acuífero del Valle de San Luis Potosí. (G. Santacruz de León and A. Ramos leal, Eds.) El Colegio de San Luis, San Luis Potosí, Mexico, pp. 23-43.

Caravaca F., Lax A. and Albaladejo J. (2001). Soil aggregate stability and organic matter in clay and fine silt fractions in urban refuse-amended semiarid soils. Soil Sci. Soc. Am. J. 65 (4), 1235-1238.

DOI: $10.2136 /$ sssaj2001.6541235x

Chen W., Westerhoff P., Leenheer J. A. and Booksh K. (2003). Fluorescence excitation- emission matrix 
regional integration to quantify spectra for dissolved organic matter. Environ. Sci. Technol. 37 (24), 57015710. DOI: $10.1021 / \mathrm{es} 034354 \mathrm{c}$

Chen Y., Dosoretz C.G., Katz I., Jüeschke E., Marschner B. and Tarchitzky J. (2010). Organic matter in wastewater and treated wastewater-irrigated soils: Properties and effects. In: Treated wastewater in agriculture: Use and impacts on the soil environment and crops. (G. J. Levy, P. Fine and A. Bar-Tal, Eds.). Wiley-Blackwell, Oxford, UK, pp. 400-417.

DOI: $10.1002 / 9781444328561 . c h 13$

Cirelli C. (2004). Agua desechada, agua aprovechada: cultivando en las márgenes de la ciudad. San Luis Potosí, San Luis Potosí, México. El Colegio de San Luis, San Luis Potosí, Mexico, 224 pp.

Clemente J. S., Simpson A. J. and Simpson M. J. (2011). Association of specific organic matter compounds in size fractions of soils under different environmental controls. Org. Geochem. 42 (10), 1169-1180.

DOI: $10.1016 /$ j.orggeochem.2011.08.010

CONAGUA (2014). Estadísticas del agua en México edición 2014. Comisión Nacional del Agua. [online] http://www.conagua.gob.mx/CONAGUA07/Publicaciones/Publicaciones/EAM2014.pdf 30/03/2017

Corral-Nuñez G., Opazo-Salazar D., GebreSamuel G., Tittonell P., Gebretsadik A., Gebremeskel Y. and Beek C. L. (2014). Soil organic matter in Northern Ethiopia, current level and predicted trend: a study case of two villages in Tigray. Soil Use Manage. 30 (4), 487-495. DOI: 10.1111 sum.12157

Davel M. and Ortega A. (2003). Estimación del índice de sitio para pino oregón a partir de variables ambientales en la Patagonia Andina Argentina. Bosque (Valdivia), 24 (1), 55-69.

DOI: $10.4067 / \mathrm{S} 0717-92002003000100005$

Ding F., Cai J., Xu X. and Yang Y. (2011). Characteristics of soluble organic matter combined with $<2 \mathrm{mu}$ clay size fraction of source rocks and its significance. J. Tongji Univ. (Nat. Sci.) 39 (11), 1710-1714.

Domènech X. and Peral J. (2006). Química ambiental de sistemas terrestres. Reverte S.A. Barcelona, España, $256 \mathrm{pp}$.

Drewes J. E., Quanrud D. M., Amy G. L. and Westerhoff P. K. (2006). Character of organic matter in soilaquifer treatment systems. J. Environ. Eng. 132 (11), 1447-1458.

DOI: 10.1061/(ASCE)0733-9372(2006)132:11(1447)

Edwards L., Burney J. R., Richter G. and MacRae A. H. (2000). Evaluation of compost and straw mulching on soil-loss characteristics in erosion plots of potatoes in Prince Edward Island, Canada. Agr. Ecosyst. Environ. 81 (3), 217-222.

DOI: $10.1016 / \mathrm{S} 0167-8809(00) 00162-6$
FAO (2013). Statistical yearbook. World food and agriculture. Food and Agriculture Organization of the United Nations. Rome, Italy, $288 \mathrm{pp}$.

Fassbender H. (1994). Química de suelos con énfasis en suelos de América Latina. 2a. Reimpresión. Instituto Interamericano de Cooperación para la Agricultura, San José Costa Rica, Costa Rica, 420 pp.

Feigin A., Ravina I. and Shalhevet J. (1991). Irrigation with treated sewage effluent. Management for environmental protection. Springer, Berlin Heidelberg, New York, USA, $200 \mathrm{pp}$.

Fine P., Hass A., Prost R. and Atzmon N. (2002). Organic carbon leaching from effluent irrigated lysimeters as affected by residence time. Soil Sci. Soc. Am. J. 66 (5), 1531-1539. DOI: 10.2136/sssaj2002.1531

Filip Z. and Kubát J. (2001). Microbial utilization and transformation of humic substances extracted from soils of long-term field experiments. Eur. J. Soil Biol. 37 (3), 167-174.

DOI: $10.1016 /$ S1164-5563(01)01080-9

Fonseca A. F. D., Herpin U., Paula A. M. D., Victória R. L. and Melfi A. J. (2007). Agricultural use of treated sewage effluents: agronomic and environmental implications and perspectives for Brazil. Sci. Agr. 64 (2), 194-209. DOI: $10.1590 / \mathrm{S} 0103-90162007000200014$

Friedel J. K., Langer T., Siebe C. and Stahr K. (2000). Effects of long-term waste water irrigation on soil organic matter, soil microbial biomass and its activities in central Mexico. Biol. Fert. Soils 31 (5), 414-421. DOI: $10.1007 / \mathrm{s} 003749900188$

Fuentes Rivas R. M., Ramos Leal J. A., Jiménez Moleón M. D. C. and Esparza Soto M. (2015). Caracterización de la materia orgánica disuelta en agua subterránea del Valle de Toluca mediante espectrofotometría de fluorescencia 3D. Rev. Int. Contam. Ambie. 31 (3), 253-264.

Fuentes-Rivas R. M., Ramos-Leal J. A., Moran-Ramírez J. and Esparza-Soto M. (In press). Methodology with 3D Fluorescence Spectroscopy to Characterize Dissolved Organic Matter in Soil. Nova Science Publisher, Inc.

Gotosa J., Nezandonyi K., Kanda A., Mushiri S.M., Kundhlande A. and Nyamugure T. (2011). Effects of irrigating Eucalyptus grandis plantations with a mixture of domestic and pulp and paper mill effluent on soil quality at a site in northern Zimbabwe. J. Sustain. Develop. in Africa. 13 (5), 136-149.

Guggenberger G., Zech W. and Schulten H. R. (1994). Formation and mobilization pathways of dissolved organic matter: evidence from chemical structural studies of organic matter fractions in acid forest floor solutions. Org. Geochem. 21 (1), 51-66.

DOI: 10.1016/0146-6380(94)90087-6 
Guggenberger G. and Kaiser K. (2003). Dissolved organic matter in soil: challenging the paradigm of sorptive preservation. Geoderma 113 (3-4), 293-310.

DOI: $10.1016 / \mathrm{S} 0016-7061(02) 00366-X$

Hernandez-Soriano M.C., Sevilla-Perea A., Kerré B. and Mingorance M.D. (2013). Stability of oganic matter in anthropic soils: A spectroscopic approach. In: Soil processes and current trends in quality assessment. (M. C. Hernandez Soriano, Ed.). InTech Open Access Publisher, Shangai, China, pp 231-247.

DOI: $10.5772 / 55632$

Ibarra-Castillo D., Ruiz-Corral J. A., Flores-Garnica J. G. and González-Eguiarte R. D. (2007). Distribución espacial del contenido de materia orgánica de los suelos de Zapopan, Jalisco. Terra Latinoamericana 25 (2), 187-194.

Jiménez B. (2005). Treatment technology and standards for agricultural wastewater reuse: a case study in Mexico. Irrig. Drain. 54 (1), 23-35. DOI: 10.1002/ird.183

Jueschke E., Marschner B., Tarchitzky J. and Chen Y. (2008). Effects of treated wastewater irrigation on the dissolved and soil organic carbon in Israeli soils. Water Sci. Technol. 57 (5), 727-733.

DOI: $10.2166 /$ wst.2008.173

Jüschke E. (2009). Effluent irrigation and agricultural soils: effects on the dynamics of organic carbon and microbial activity in agricultural soils in Israel. Verlag Dr. Kovač, Verlag, Hamburg, 336 pp.

Kalbitz K. and Popp P. (1999). Seasonal impacts on $\beta$-hexachlorocyclohexane concentration in soil solution. Environ. Pollut. 106 (1), 139-141. DOI: 10.1016/S0269-7491(99)00059-7

Kalbitz K., Solinger S., Park J. H., Michalzik B. and Matzner E. (2000). Controls on the dynamics of dissolved organic matter in soils: A review. Soil science. Bd. 165 (4), 277-304.

DOI: 10.1097/00010694-200004000-00001

Kaushik A., Nisha R., Jagjeeta K. and Kaushik C. P. (2005). Impact of long and short term irrigation of a sodic soil with distillery effluent in combination with bioamendments. Bioresour. Technol. 96 (17), 1860-1866.

DOI: 10.1016/j.biortech.2005.01.031

Lehmann J., Kinyangi J. and Solomon D. (2007). Organic matter stabilization in soil microaggregates: implications from spatial heterogeneity of organic carbon contents and carbon forms. Biogeochemistry 85 (1), 45-57.

DOI: $10.1007 / \mathrm{s} 10533-007-9105-3$

Lundström C. C., Gill J., Williams Q. and Perfit M. R. (1995). Mantle melting and basalt extraction by equilibrium porous flow. Science 270 (5244), 1958-1961. DOI: $10.1126 /$ science. 270.5244 .1958
Mavi M.S. (2012). Dissolved organic matter dynamics and microbial activity in salt-affected soils. Doctoral Thesis. University of Adelaide Australia, Australia, 146 pp.

Mayer L. M. and Xing B. (2001). Organic matter-surface area relationships in acid soils. Soil Sci. Soc. Am. J. 65 (1), 250-258. DOI: 10.2136/sssaj2001.651250x

Mayer L. M., Schick L. L., Hardy K. R., Wagai R. and McCarthy J. (2004). Organic matter in small mesopores in sediments and soils. Geochim. Cosmochim. Ac. 68 (19), 3863-3872. DOI: 10.1016/j.gca.2004.03.019

McDowell W. H. and Likens G. E. (1988). Origin, composition, and flux of dissolved organic carbon in the Hubbard Brook Valley. Ecol. Monogr. 58 (3), 177-195. DOI: $10.2307 / 2937024$

Meli S., Porto M., Belligno A., Bufo S. A., Mazzatura A. and Scopa A. (2002). Influence of irrigation with lagooned urban wastewater on chemical and microbiological soil parameters in a citrus orchard under Mediterranean condition. Sci. Total Environ. 285 (1), 69-77.

Metcalf and Eddy (2003). Wastewater engineering - Treatment and reuse. 4a ed. McGraw-Hill, Inc., New York, USA, $1771 \mathrm{pp}$.

Morgan R. P. C. (2005). Soil erosion and conservation. 3a ed. Blackwell Publishing, Oxford, UK, 316 pp.

Morugán-Coronado A., García-Orenes F., Mataix-Solera J., Arcenegui V. and Mataix-Beneyto J. (2011). Short-term effects of treated wastewater irrigation on Mediterranean calcareous soil. Soil Till. Res. 112 (1), 18-26. DOI: 10.1016/j.still.2010.11.004

Mostofa K. M. and Sakugawa H. (2009). Spatial and temporal variations and factors controlling the concentrations of hydrogen peroxide and organic peroxides in rivers. Environ. Chem. 6 (6), 524-534.

DOI: $10.1071 /$ EN09070

Navarro Blaya S. and Navarro García G. (2003). Química agrícola: el suelo y los elementos químicos esenciales para la vida vegetal. Mundi-Prensa Libros. Madrid, España, 487 pp.

Nadav I., Tarchitzky J., Lowengart-Aycicegi A. and Chen Y. (2013). Soil surface water repellency induced by treated wastewater irrigation: physico-chemical characterization and quantification. Irrigation Sci. 31 (1), 49-58. DOI: 10.1007/s00271-011-0291-3

Nikolskii-Gavrilov I., Aidarov I. P., Landeros-Sánchez C., Herrera-Gómez S. and Bakhlaeva-Egorova O. (2014). Evaluation of soil fertility indices of freshwater irrigated soils in Mexico across different climatic regions. J. Agr. Sci. 6 (6), 98. DOI: 10.5539/jas.v6n6p98

Ohno T., Fernández I. J., Hiradate S. and Sherman J. F. (2007). Effects of soil acidification and forest type on water soluble soil organic matter properties. Geoderma 140 (1-2), 176-187.

DOI: $10.1016 /$ j.geoderma.2007.04.004 
Prasad R. and Power J.F. (1997). Soil fertility management for sustainable agriculture. Lewis Publishers. New York, USA, 384 pp.

Quanrud D. M., Arnold R. G., Wilson L. G., Gordon H. J., Graham D. W. and Amy G. L. (1996). Fate of organics during column studies of soil aquifer treatment. J. Environ. Eng. 122 (4), 314-321.

Quanrud D. M., Hafer J., Karpiscak M. M., Zhang J., Lansey K. E. and Arnold R. G. (2003). Fate of organics during soil-aquifer treatment: sustainability of removals in the field. Water Res. 37 (14), 3401-3411. DOI: 10.1016/S0043-1354(02)00489-X

Rusan M. J. M., Hinnawi S. and Rousan L. (2007). Long term effect of wastewater irrigation of forage crops on soil and plant quality parameters. Desalination 215 (13), 143-152. DOI: 10.1016/j.desal.2006.10.032

Saadi I., Borisover M., Armon R. and Laor Y. (2006). Monitoring of effluent DOM biodegradation using fluorescence, UV and DOC measurements. Chemosphere 63 (3), 530-539.

DOI: $10.1016 /$ j.chemosphere.2005.07.075

Salazar-Ledesma M. (2011). Evaluación del grado de contaminación de la zona Noreste del acuífero somero del Valle de San Luis Potosí, asociado al riego con agua residual. Tesis de Maestría. Universidad Autónoma de México, Mexico City, Mexico, 128 pp.

Sarabia- Meléndez I.F., Cisneros-Almazán R., Aceves de Alba J., Durán-García H.M. and Castro-Larragoitia J. (2011). Calidad del agua de riego en suelos agrícolas y cultivos del Valle de San Luis Potosí, México. Rev. Int. Contam. Ambie. 27 (2):103-113.

SEMARNAT (2000). Norma Oficial Mexicana NOM021-SEMARNAT-2000. Que establece las especificaciones de fertilidad, salinidad y clasificación de suelos, estudio, muestreo y análisis. Diario Oficial de la Federación. 31 de diciembre de 2002.

Stevenson F. J. (1994). Humus chemistry: genesis, composition, reactions. $2 \mathrm{a}$ ed. Wiley Interscience. New York, USA, 512 pp.

Sustaita F., Ordaz V., Ortiz C. and De León F. (2000). Cambios en las propiedades físicas de dos suelos de la región semiárida debido al uso agrícola. Agrociencia 34, 379-386.

Thompson L.M. and Troeh F.R. (1988). Los suelos y su fertilidad. 4a ed. Reverte S.A. Barcelona, España, $661 \mathrm{pp}$.

Traversa A., D’Orazio V. and Senesi N. (2008). Properties of dissolved organic matter in forest soils: influence of different plant covering. Forest Ecol. and Manag. 256 (12), 2018-2028.

DOI: $10.1016 /$ j.foreco.2008.07.038
USDA (2015). Natural resources conservation service. Illustrated guide to soil taxonomy. National Soil Survey Center, United States Department of Agriculture. Lincoln, Nebraska, USA, 681 pp.

Walkley A. and Black I. A. (1934). An examination of the Degtjareff method for determining organic carbon in soils: Effect of variations in digestion conditions and of inorganic soil constituents. Soil Sci. 63, 251-263.

Walker S. and Lin H. (2008). Soil property changes after four decades of wastewater irrigation: a landscape perspective. Catena 73, 63-74.

DOI: $10.1016 /$ j.catena.2007.09.002

Westerhoff P. and Pinney M. (2000). Dissolved organic carbon transformations during laboratory-scale groundwater recharge using lagoon-treated wastewater. Waste Manage. 20 (1), 75-83. DOI: 10.1016/S0956-053X(99)00277-9

Xue S., Zhao Q. L., Wei L. L. and Ren N. Q. (2009). Behavior and characteristics of dissolved organic matter during column studies of soil aquifer treatment. Water Res. 43 (2), 499-507.

DOI: $10.1016 /$ j.watres.2008.10.026

Xue S., Zhao Q., Wei L., Song Y. and Tie M. (2013). Fluorescence spectroscopic characterization of dissolved organic matter fractions in soils in soil aquifer treatment. Environ. Monit. Assess. 185 (6), 4591-4603. DOI: $10.1007 / \mathrm{s} 10661-012-2890-8$

Yuan Y., Zhou S.G., Yuan T., Zhuang L. and Li F.B. (2013). Molecular weight-dependent electron transfer capacities of dissolved organic matter derived from sewage sludge compost. J. Soil Sediment. 13 (1), 56-63. DOI: $10.1007 / \mathrm{s} 11368-012-0585-\mathrm{y}$

Zech A. and Guggenberger G. (1996). Organic matter dynamics in forest soils of temperate and tropical ecosystems. In: Humic substances in terrestrial ecosystems. (A. Piccolo, Ed.). Elsevier, Amsterdam, Holanda, pp.101-170.

DOI: 10.1016/B978-044481516-3/50004-9

Zhao Y., He X. S., Xi B. D., Wei D., Wei Z. M., Jiang Y. H. and Yang T. X. (2010). Effect of $\mathrm{pH}$ on the fluorescence characteristic of dissolved organic matter in landfill leachate. Guang Pu Xue Yu Guang Pu Fen Xi. $30(2), 382-6$.

Zsolnay A. (2003). Dissolved organic matter: artefacts, definitions, and functions. Geoderma 113 (3-4), 187-209.

DOI: $10.1016 / \mathrm{S} 0016-7061(02) 00361-0$ 